\title{
OBITUARIES
}

\section{Prof. F. Debenham}

Prof. Frank Debenham had been a colleague, friend and helpor to so many that his death on November 23, 1965, at the age of eighty-one brings sadness to all. His was a life of vigour and indeed of vision, for he constantly looked ahead to new organizations and new methods which should be improvements on those already in being. Into old age he retained his enthusiasms, his friendships and his continued interest and writing on a variety of small but always practical topics in the realms of eartography and survey. Not least he remained fascinated by those frozen fishes which appeared so mysteriously on the surface of the Ross Ice Shelf and which excited such interesting hypotheses about the nourishment of ice shelves by the freezing of sea-water.

Born in Australia in 1883, Debenham was of the right age and training to become geologist to Scott's second Antaretic Expedition between 1910 and 1913. There he did much valuable work and forged the links of friendship with Sir Raymond Priestley and Sir Charles Wright, which later bore such excellent fruit in the foundation of the Scott Polar Research Institute in Cambridge. Intervening war service and wounding in Salonika preceded his return to Cambridge and his appointment in 1919 as Royal Geographical Society lecturer in cartography. There he soon succeeded Philip Lake as reader in geography, and not long afterwards had the distinetion of being appointed the first holder of the new ehair of geography in the University of Cambridge. His activities were such that by 1936 the new Department had been built and was well on the way towards that distinetion which it possessed by the time of his retirement from the chair in 1949.

Yet many will think of 'Deb' primarily as the 'architect' of the Scott Polar Research Institute, of which he was part-founder and director from 1925 until 1946. The death of Seott and his companions returning from the South Pole in 1912 had stirred Britons perhaps more than any other peacetime event in centuries. They rallied nobly to Scott's last appeal to "see that those who are dependent on us are properly provided for". The subsequent Mansion House Fund reached a total of $£ 76500$, a large sum at that time.

When the Mansion House Fund had fulfilled its dual task of providing for dependants and of publishing the scientific reports, there still remained a sum of $£ 15,000$ set aside as a 'Polar Research Fund'. It was in the early 'twenties that Debenham, before ever he was professor, put forward proposals which sprang from discussions a decade before in Antaretica with Raymond Priestley and Charles Wright. Their practical idealism was now to bear fruit. Debenham was able to show convineingly that often hard-won experience of polar expeditions in the past had been lost when their members dispersed, and that the techniques of life and travel in cold regions had been inadequately recorded. To ensure that future oxpeditions might fully profit from the past, on the sure basis of recorded experience, Deb proposed the foundation of an institute for polar research. That was the origin of the Scott Polar Research Institute in Cambridge-first an idea; then a tiny beginning in an attic room in the Sedgwick Museum of Geology in 1920; later, the construction, with the residue of the Mansion House Fund, of a particularly beautiful small building opened in 1934; and gradually the growth of the Institute to its present position of international repute. Deb happily lived to know of the recent munificent bequest from the Ford Foundation which will now allow the Institute, which was so elose to his heart, to expand anew some 40 years after he had laid the first foundation.

$$
\text { G. C. L. Bertram }
$$

\section{Prof. José María Albareda}

Prof. José María Albareda died in Madrid on March 27, within a few days of his sixty-fourth birthday. Albareda was born in Caspe. He studied at the University of Madrid, where he graduated in pharmacy, obtaining his doctorate in 1927. He then studied chemistry in the Faculty of Science in Zaragoza and obtained his doctorate in chemistry in 1931. He immediately embarked on his career of soil research, at first under Prof. Rocasolano and Rius Miró in the University of Zaragoza. Between 1935 and 1936 he developed a course in soil science while holding the Conde de Cartagena chair of the Royal Academy of Science of Spain.

He was the first director of the Institute Ramiro de Maeztu of Madrid, and in 1940 was appointed to the chair of geology and zoology in the Faculty of Pharmacy in the University of Madrid, where he remained until his retirement in 1959. He helped towards the development of the new University of Navarra at Pamplona, and was appointed rector in 1960 , a position he held at the time of his death. In 1959 he was ordained a priest.

Albareda was a leader in the field of pure and applied research, and with considerable foresight he, in collaboration with various university professors, planned the development of research in Spain, particularly through his service to the Spanish Research Council. After the foundation of the Consejo Superior de Investigaciones Científicas in 1939 he was appointed general secretary, and remained so until his death. Albareda directed much of his attention towards the development of soil science and to the problem of development of agriculture in Spain. He was in charge of the Instituto de Edafología from its formation in 1942 until his death. During this period the work performed by Albareda and his colleagues covered a wide field of soil science and had important practical applications. During the 26 years in which Albareda was general secretary in the Council he built up an extensive research programme with a great number of centres in Madrid and other cities entirely dedicated to research, and he established the foundation of a new era in the history of Spain.

The work of Prof. Albareda received international acclaim and he was elected corresponding, foreign or honorary member of a number of European societies. He was awarded a great number of distinctions, including his election as a member of the Spanish Royal Academy of Science in 1941, of Pharmacy in 1941, and of Medicine in 1952, of the Pontifical Academy of Sciences of the Vatican in 1948, and also of the Royal Academies of Seience of Barcelona and Zaragoza.

\section{Prof. George Humphrey}

THE death of George Humphrey at the age of seventysix on April 24 has removed one of the last surviving links in Great Britain with the pioneer psychological laboratory of Wilhelm Wundt at Leipzig. He acquired at Leipzig a 